\title{
Decision support system for football player's position with tsukamoto fuzzy inference system
}

\author{
Yana Aditia Gerhana, Wildan Budiawan Zulfikar, Yuga Nurrokhman, Cepy Slamet, and Muhammad Ali Ramdhani* \\ UIN Sunan Gunung Djati Bandung, Department of Informatics, Jl. A.H. Nasution No. 105, Bandung, Indonesia
}

\begin{abstract}
Nowadays, football is one of the most famous sports in the world. Many football clubs and football academies have been established in Indonesia. In football academy, each player will be trained and selected to get the best positon in the team formation. In fact, each player has a different ability and skill. If a player gets a correct position, he can open the opportunity for his team to win a competition. This condition absolutely gives a good impact for the team. However, it will be a serious problem if a player plays in an incorrect position. The player's best position can be deciding by his own ability and skill. This study proposes the selection model of player's position by understanding a player's speed, stamina, strength, and other skills that covering, shooting, passing, dribble, and header with Tsukamoto Fuzzy Inference System. A player may have the following positions: central forward, midfielder, winger, goal keeper. In evaluation phase, this model exactly shows $52.17 \%$ accurate value. This means that the model decreases the misplacement of player's position. It is recommended for further study to make some additional criteria such as player's emotion, attitude, etc in order to increase accurate.
\end{abstract}

\section{Introduction}

Football is one of the most famous sports in the world. This sport is played by millions of people and also various ages, both men, women, children, young and adult. Currently, many football academies are established in Indonesia with the aim to build young talents to become professional players in the country and abroad [1-4].

However, many football academics forget that the real achievement is the overall formation of players, techniques (how to do things), tactics (understanding the game or understanding of why to do something), physically and mentally (forging a positive and strong character that is so important both for the life of the player as a whole and for his development as a football player). Assessment of the characteristics or specifications of a player can be seen how and the physical strength (speed and agility, endurance,), (technique, passing and receiving, shooting, ball control and turning) ball possession and transition $[5,6]$.

The utilization of information technology in the world of football, especially in the process of selecting players and in the process of placing the player's position to match the characters and criteria of players who are expected to be not optimal and not computerized. In fact, in the process of player settlement and player placement selection is still done manually using paper form in the judgment of players who are wasting time and place [7].

According to observation, many coaches have difficulty determining the position of players for their potential players, because there are still many coaches who judge a player not objectively. A coach uses only their instinct to assess a player. For examples, a player that a good defender positioned as a striker, or otherwise a supposedly a striker but positioned as a defender so that the placement is not in accordance with skill or criteria and the ability of a player [4].

The purpose of this work is to design decision support system with tsukamoto fuzzy inference system to assist coach in order to decide best player's position. This method is chosen because this method determines the weight value for each attribute, followed by a ranking process that will select the best alternative from a number of alternatives. This method allows each rule to be represented using fuzzy sets, with a monotonous membership function in order to determine the output value of a result is searched by changing the input (a fuzzy set obtained from the composition of fuzzy rules) into a number in the fuzzy set domain. This method also called the defuzzification method (affirmation). The defuzzification method used in the Tsukamoto method is the central average defuzzification method (Center Average Defuzzyfier) [5].

The development method implemented in this work is the RUP (rational unified process) used in the application using the Prototype model where this method is to allow the user to be able to make changes.

\section{Literature Review}

\subsection{Decision support system}

Technological devices are designed to enhance a quality of human's life [8], one of those which are enable efficiency and effectiveness in business process within a field of

\footnotetext{
*Corresponding author: m_ali_ramdhani@uinsgd.ac.id
} 
decision making is information systems [9]. This systems is a combination of information technology utilizations and human activity upon a set of agreed procedures, IS has a high level of flexibilities to develop and scalable [10], Decision Support System (DSS) is generally known as a branch of IS applications. Refers to several research, IS has a high capability in decision making, the system has an accurate data accessibility and efficient run-time [11,12], high accuracy $[13,14]$, and to support a proper decision $[15,16]$, low cost [17], extended accessibility [18], intensify user knowledge [19,20], increase productivity [21][15], provide a better data and information [22,23], and in used as data storage [24,25].

Decision Support System can be defined as a computer-based system consisting of 3 (three) interacting components:

a. Language system (mechanism to provide communication between users and other DSS components)

b. System knowledge (repository knowledge domain problem existing on DSS either as data or as procedure),

c. the processing system (the relationship between two other components, consisting of one or more manipulation capabilities of common problems needed for decision making) [26].

The concepts given by the definition are very important to understand the relationship between DSS and knowledge. Decision Support System includes 4 main components (subsystem), namely data management, model management, user interface and knowledge-based management $[26,27]$.

A system can be regarded as a decision support system if it meets the requirements as follows: requires hardware, requires software, requires human (designer and user), designed to support a decision-making, must be able to assist decision makers at each decision level, and Emphasize unstructured or semi-structured issues [27].

\subsection{Fuzzy logic}

Fuzzy logic is one of the components of soft computing. Fuzzy logic was first introduced by prof. Lotfi A. Zadeh in 1965. The basis of fuzzy logic is the theory of the fuzzy set. In the fuzzy set theory, the role of membership degree as a determinant of the existence of elements in a set is very important. The membership value or membership degree or membership function is the main characteristic and reasoning with that logic $[28,29]$.

Fuzzy logic is one of the components of soft computing. Fuzzy logic was first introduced by prof. Lotfi A. Zadeh in 1965. The basis of fuzzy logic is the fuzzy set theory. In the fuzzy set theory, the role of membership degree as a determinant of the existence of elements in a set is very important. Membership membership values are the main characteristic of reasoning with the fuzzy logic [28].

Decision support systems also need information technology, this is because of the era of globalization, which requires a company to move quickly in taking a decision $\&$ action with reference to the solution given by
Tsukamoto fuzzy inference system method in helping to make decisions. One of them is decision making in giving reward which is proper for waiter who give service on time according to customer wishes at a restaurant. Fuzzy logic can be considered as a black box that relates between the input space to the output space $[30,29]$.

\subsection{Tsukamoto fuzzy inference system}

Tsukamoto's method is an extension of monotonous reasoning, in Tsukamoto's Method, every consequence of the IF-Then rule must be represented by a fuzzy set with a monotonous köping function. As a result, the inference output of each rule is given explicitly based on the predicate. The end result is obtained by using weighted averages $[28,31,32]$. This method mainly implemented in several field as follow: promotion system, multimedia, game, education, etc. [21,33-35].

This method, each rule is represented using fuzzy sets, with a monotonous membership function. To determine the output value of crisp / firm result (Z) is searched by changing the input (a fuzzy set obtained from the fuzzy rule composition) into a number in the fuzzy set domain. This method is called the defuzzification method (affirmation). The defuzzification method used in the Tsukamoto method is the central average defuzzification method (Center Average Defuzzyfier) [28].

Conjunction of Tsukamoto fuzzy

$$
\mu \mathrm{A} \wedge \mathrm{B}=\mu \mathrm{A}(\mathrm{x}) \cap \mu \mathrm{B}(\mathrm{y})=\min (\mu \mathrm{A}(\mathrm{x}), \mu \mathrm{B}(\mathrm{y}))
$$

Disjunction of tsukamoto fuzzy

$$
\mu \mathrm{A} \vee \mathrm{B}=\mu \mathrm{A}(\mathrm{x}) \cup \mu \mathrm{B}(\mathrm{y})=\max (\mu \mathrm{A}(\mathrm{x}), \mu \mathrm{B}(\mathrm{y}))
$$

In the Tsukamoto method, the implications of each rule are in the form of "cause" implications / Input-Output Implications. Example: Suppose there are two input variables Var-1 (x) \& Var-2 (x), as well as output variables Var-3 (z), where Var-1 is divided into 2 sets ie A1 \& A2. Var-2 is divided into 2 sets B1 \& B2, Var-3 jg is divided into 2 sets ie $\mathrm{C} 1 \& \mathrm{C} 2(\mathrm{C} 1 \& \mathrm{C} 2$ must be monotone) $[36,31,28,37]$.

[R1] IF ( $\mathrm{x}$ is $\mathrm{A} 1$ ) and (y is B2) THEN ( $\mathrm{z}$ is $\mathrm{C} 1$ )

[R2] IF ( $\mathrm{x}$ is A2) and ( $\mathrm{y}$ is B1) THEN ( $\mathrm{z}$ is $\mathrm{C} 2)$

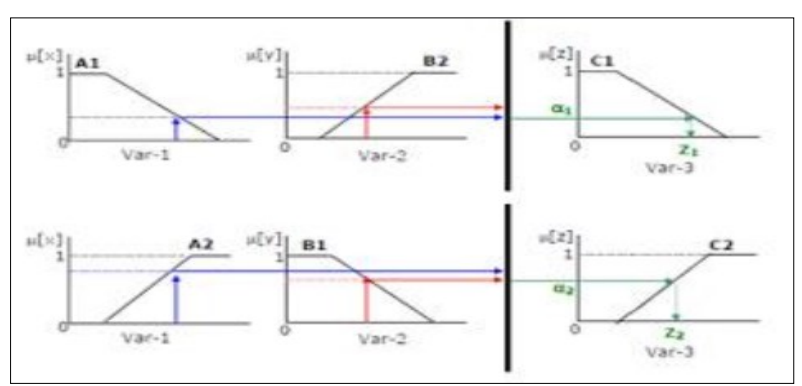

Fig. 1. Tsukamoto Fuzzy. 


\section{Experiments}

\subsection{Inception}

Accodring to obseration phase, we found a coach that have less precise in determining the ideal position of the player because it only relies on the instincts of the coach and the ego of his players and there are still coaches who have not been able to assess the player objectively. Manual data processing is not effective enough because of the dynamic development of the player so it requires an application can process the data into an information that can help the coach in the decision-making process.

\subsection{Elaboration}

According to real football, this work implement several position as follow CF (Central Forward), AMF (Attacking Midfielder), DMF (Defensive Midfielder), WB (Wing Back), WG (Winger), GK (Goal Keeper). Table 1 descibe team assessment with several current position.

Table 1. Team Assessment.

\begin{tabular}{|c|c|c|c|c|c|c|c|c|c|c|}
\hline No. & $\frac{\dot{\Xi}}{\grave{\Delta}}$ & 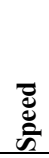 & 营 & 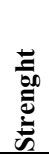 & 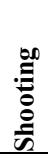 & 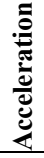 & 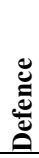 & 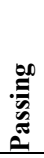 & $\frac{0}{0}$ & 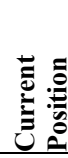 \\
\hline 1 & S01 & 84 & 87 & 95 & 56 & 81 & 71 & 83 & 80 & GK \\
\hline 2 & $\mathrm{~S} 02$ & 73 & 60 & 88 & 45 & 73 & 56 & 65 & 58 & GK \\
\hline 3 & S03 & 80 & 80 & 80 & 90 & 80 & 30 & 80 & 80 & $\mathrm{CF}$ \\
\hline 4 & S04 & 90 & 90 & 90 & 95 & 90 & 65 & 95 & 95 & $\mathrm{AMF}$ \\
\hline 5 & S05 & 75 & 70 & 72 & 65 & 65 & 75 & 73 & 63 & $\mathrm{AMF}$ \\
\hline 6 & S06 & 69 & 76 & 90 & 55 & 55 & 82 & 70 & 59 & $\mathrm{CB}$ \\
\hline 7 & S07 & 75 & 90 & 74 & 83 & 74 & 85 & 80 & 77 & DMF \\
\hline 8 & S08 & 53 & 77 & 96 & 53 & 49 & 94 & 75 & 62 & $\mathrm{CB}$ \\
\hline 9 & S09 & 82 & 76 & 79 & 55 & 79 & 89 & 81 & 68 & $\mathrm{CB}$ \\
\hline 10 & $\mathrm{~S} 10$ & 61 & 78 & 91 & 48 & 60 & 92 & 70 & 55 & $\mathrm{CB}$ \\
\hline
\end{tabular}

\subsubsection{Use case Diagram}

The proposed work implement a system with one actor and several use case as follow: entry player, manage ability, manage formation, and show recommendation that describe in detail on fig. 2.

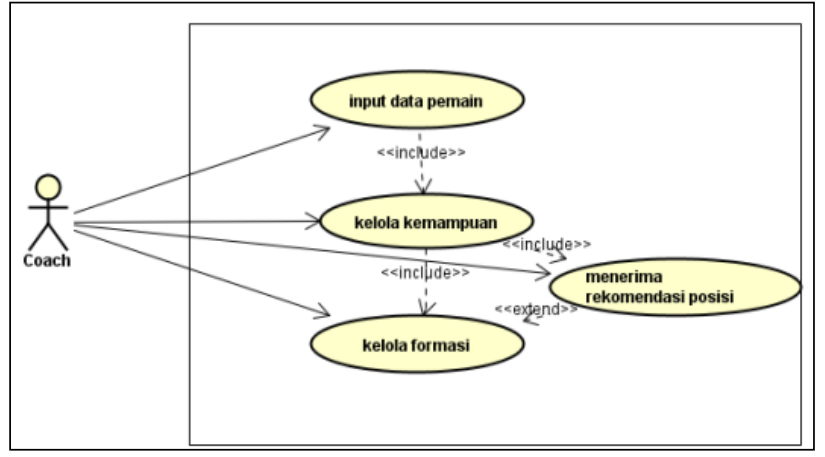

Fig. 2. Use Case Diagram.

\subsubsection{Class Diagram}

This app developed by object oriented programming. There are several class that implemented as follow: player, formation, ability, etc technically describe in fig. 3 .

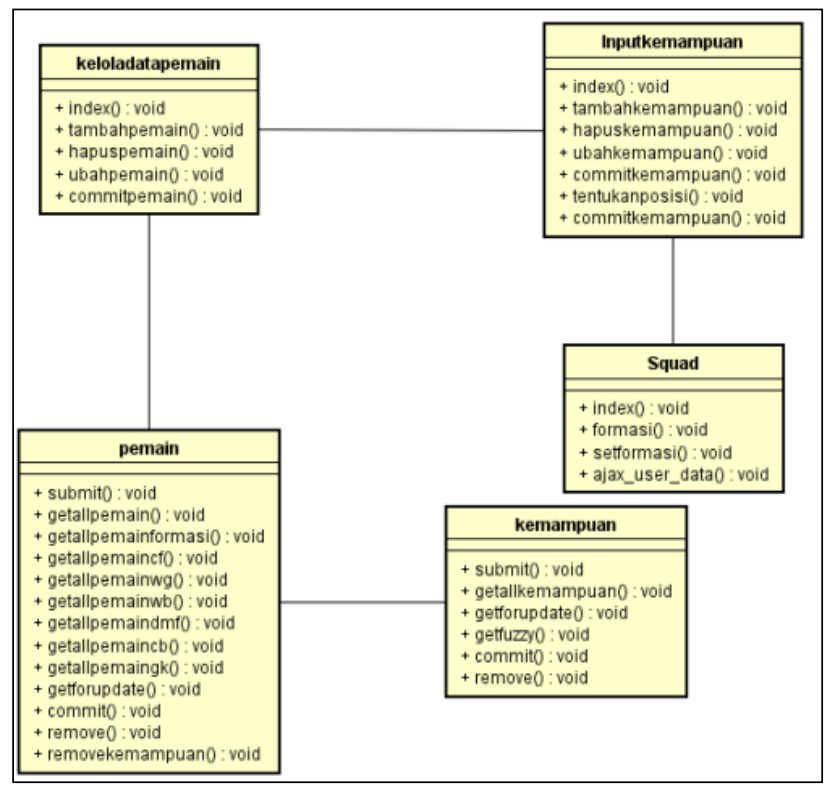

Fig. 3. Class Diagram.

\subsubsection{Physical Data Model}

In data model, this app using two main table (player and ability). Fig. 4 describe that a relationship between player and ability. One player may have one or more ability set. Before training, a player's ability assessed and stored and also after training and several time later. Therefore the relation between player and ability are one to many, in detail one for plyaer and many for ability.

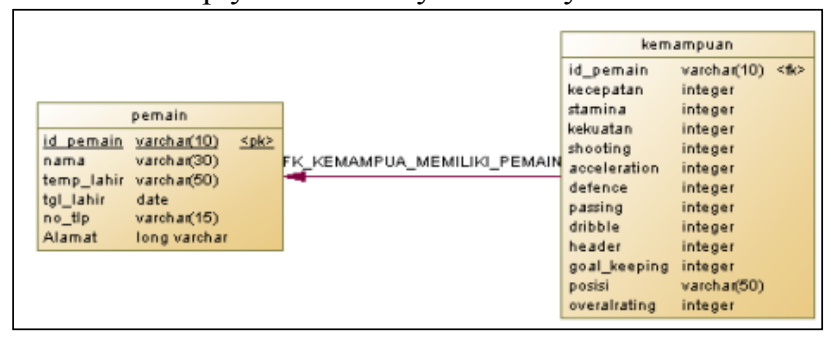

Fig. 4. Physical Data Model. 


\subsection{Construction}

This app constructed as a web based application with aplied responsive webpage. Fig. $5 \mathrm{a}$ and $\mathrm{b}$ describe mockup preview of the app. Fig. 5a describe the main menu and fig. $5 \mathrm{~b}$ describe formation menu.

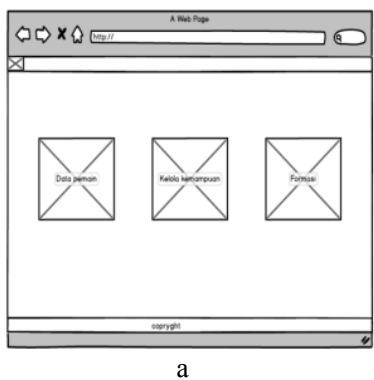

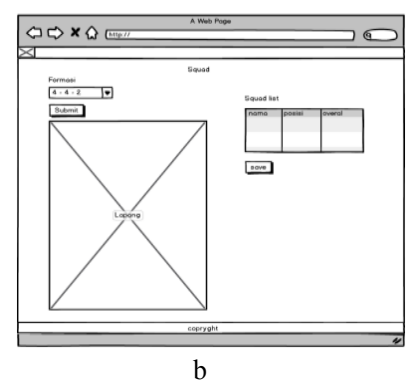

Fig. 5. Mockup of App.

Fig 6. describe user interface of main menu. There are several menu show in main menu such as player, ability, and formation.

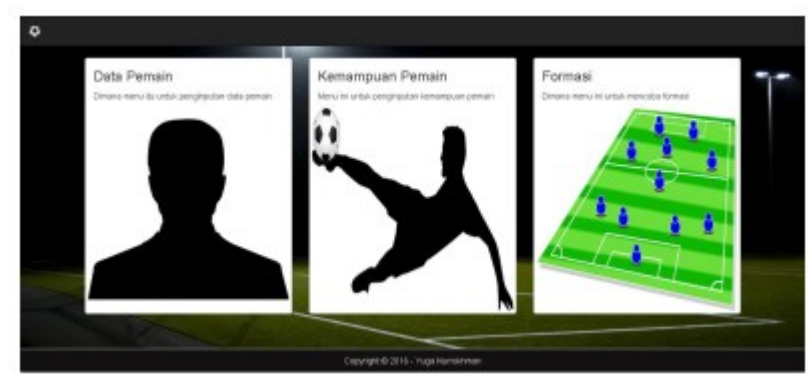

Fig. 6. User interface of main menu

Fig. 7 describe user interface of formation menu. In this menu, coach can choose several formations as follow: 3 5-2, 4-4-2, 4-5-1, etc with several modification. This menu show suggest formation with best player position of the current team's ability.

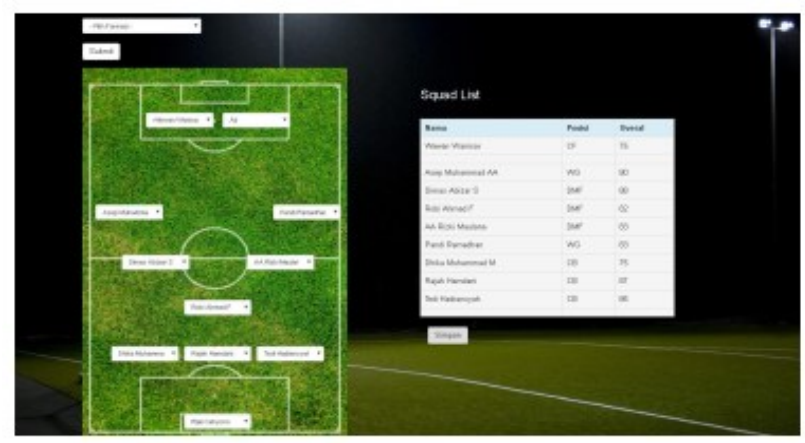

Fig. 7. Formation view of app.

\section{Result and Discussion}

This model was implement in a football academy in Indonesia. According to our observation, 12 of 23 or exactly $52.17 \%$ the player was working properly in decided position. Table 2 describe 5 samples of evaluation summary. Best position decided by senior coach in academy and recommended position decided by app.
Table 2. Evaluation Summary.

\begin{tabular}{|c|c|c|c|}
\hline No. & Player & Best Position & Recommended Position \\
\hline 1 & T01 & GK & GK \\
\hline 2 & T02 & GK & AMF \\
\hline 3 & T03 & AMF & AMF \\
\hline 4 & T04 & WG & WG \\
\hline 5 & T05 & DMF & AMF \\
\hline
\end{tabular}

\section{Conclusion}

In evaluation phase, this model exactly shows $52.17 \%$ accuration value. This means that the model decreases the misplacement of player's position. However, this model has not worked optimally. It is recommended for further study to make some additional criteria such as player's emotion, attitude, etc in order to improve accuration.

\section{References}

1. L. Held and R. Vollnhals, "Dynamic rating of European football teams," IMA J. Manag. Math., vol. 16, no. 2, pp. 121-130, Jan. (2005)

2. V. Manasis, V. Avgerinou, I. Ntzoufras, and J. J. Reade, "Quantification of competitive balance in European football: development of specially designed indices," IMA J. Manag. Math., vol. 24, no. 3, pp. 363-375, Jul. (2013)

3. D. F. Pacheco, D. Pinheiro, F. B. de Lima-Neto, E. Ribeiro, and R. Menezes, "Characterization of Football Supporters from Twitter Conversations," in 2016 IEEE/WIC/ACM International Conference on Web Intelligence (WI), pp. 169-176. (2016)

4. D. Prasetio and D. Harlili, "Predicting football match results with logistic regression," in 2016 International Conference On Advanced Informatics: Concepts, Theory And Application (ICAICTA), pp. 1-5. (2016)

5. M. A. Ikram, M. D. Alshehri, and F. K. Hussain, "Architecture of an IoT-based system for football supervision (IoT Football)," in 2015 IEEE 2nd World Forum on Internet of Things (WF-IoT), pp. 69-74. (2015)

6. L. Tianbiao and H. Andreas, "Apriori-based diagnostical analysis of passings in the football game," in 2016 IEEE International Conference on Big Data Analysis (ICBDA), pp. 1-4. (2016)

7. W. Puchun, "The Application of Data Mining Algorithm Based on Association Rules in the Analysis of Football Tactics," in 2016 International Conference on Robots \& Intelligent System (ICRIS), pp. 418-421. (2016)

8. M. A. Ramdhani, H. Aulawi, A. Ikhwana, and Y. Mauluddin, "Model of green technology adaptation in small and medium-sized tannery industry," J. Eng. 
Appl. Sci., vol. 12, no. 4, pp. 954-962, (2017)

9. A. Pamoragung, K. Suryadi, and M. A. Ramdhani, "Enhancing the implementation of e-Government in indonesia through the high-quality of virtual community and knowledge portal," in Proceedings of the European Conference on e-Government, ECEG, pp. 341-348. (2006)

10. H. Aulawi, M. A. Ramdhani, C. Slamet, H. Ainissyifa, and W. Darmalaksana, "Functional Need Analysis of Knowledge Portal Design in Higher Education Institution," Int. Soft Comput., vol. 12, no. 2, pp. 132-141, (2017)

11. C. Slamet, A. Rahman, A. Sutedi, W. Darmalaksana, M. A. Ramdhani, and D. S. Maylawati, "Social Media-Based Identifier for Natural Disaster," IOP Conf. Ser. Mater. Sci. Eng., vol. 288, no. 1, p. 012039, (2018)

12. W. B. Zulfikar, Jumadi, P. K. Prasetyo, and M. A. Ramdhani, "Implementation of Mamdani Fuzzy Method in Employee Promotion System," IOP Conf. Ser. Mater. Sci. Eng., vol. 288, no. 1, p. 012147, Jan. (2018)

13. C. Slamet, R. Andrian, D. S. Maylawati, W. Darmalaksana, and M. A. Ramdhani, "Web Scraping and Naïve Bayes Classification for Job Search Engine," vol. 288, no. 1, pp. 1-7, (2018)

14. W. B. Zulfikar, M. Irfan, C. N. Alam, and M. Indra, "The comparation of text mining with Naive Bayes classifier, nearest neighbor, and decision tree to detect Indonesian swear words on Twitter," in 2017 5th International Conference on Cyber and IT Service Management, CITSM 2017, (2017)

15. Y. A. Gerhana, W. B. Zulfikar, A. H. Ramdani, and M. A. Ramdhani, "Implementation of Nearest Neighbor using HSV to Identify Skin Disease," in IOP Conference Series: Materials Science and Engineering, vol. 288, no. 1. (2018)

16. W. B. Zulfikar, A. Wahana, W. Uriawan, and N. Lukman, "Implementation of association rules with apriori algorithm for increasing the quality of promotion," in Proceedings of 2016 4th International Conference on Cyber and IT Service Management, CITSM 2016, (2016)

17. A. Rahman, C. Slamet, W. Darmalaksana, Y. A. Gerhana, and M. A. Ramdhani, "Expert System for Deciding a Solution of Mechanical Failure in a Car using Case-based Reasoning," IOP Conf. Ser. Mater. Sci. Eng., vol. 288, no. 1, p. 012011, (2018)

18. C. Slamet, A. Rahman, M. A. Ramdhani, and W. Darmalaksana, "Clustering the Verses of the Holy Qur'an Using K-Means Algorithm," Asian J. Inf. Technol., vol. 15, no. 24, pp. 5159-5162, (2016)

19. D. S. Maylawati, M. A. Ramdhani, W. B. Zulfikar, I. Taufik, and W. Darmalaksana, "Expert system for predicting the early pregnancy with disorders using artificial neural network," in 2017 5th International Conference on Cyber and IT Service Management, CITSM 2017, (2017)

20. D. S. Maylawati, M. A. Ramdhani, W. B. Zulfikar, I. Taufik, and W. Darmalaksana, "Expert system for predicting the early pregnancy with disorders using artificial neural network," in 2017 5th International
Conference on Cyber and IT Service Management (CITSM), pp. 1-6. (2017)

21. W. B. Zulfikar, Jumadi, P. K. Prasetyo, and M. A. Ramdhani, "Implementation of Mamdani Fuzzy Method in Employee Promotion System," IOP Conf. Ser. Mater. Sci. Eng., vol. 288, no. 1, p. 012147, Jan. (2018)

22. D. S. A. Maylawati, M. A. Ramdhani, A. Rahman, and W. Darmalaksana, "Incremental technique with set of frequent word item sets for mining large Indonesian text data," 2017 5th Int. Conf. Cyber IT Serv. Manag. CITSM 2017, pp. 1-6, (2017)

23. W. B. Zulfikar and N. Lukman, "Perbandingan Naive Bayes Classifier Dengan Nearest Neighbor Untuk Identifikasi Penyakit Mata," J. Online Inform., vol. 1, no. 2, pp. 82-86, Dec. (2016)

24. A. Taofik, N. Ismail, Y. A. Gerhana, K. Komarujaman, and M. A. Ramdhani, "Design of Smart System to Detect Ripeness of Tomato and Chili with New Approach in Data Acquisition," in IOP Conference Series: Materials Science and Engineering, vol. 288, no. 1, p. 012018. (2018)

25. D. Setiawati, I. Taufik, Jumadi, and W. Z. Budiawan, "Klasifikasi Terjemahan Ayat Al-Quran Tentang Ilmu Sains Menggunakan Algoritma Decision Tree Berbasis Mobile," J. Online Inform., vol. 1, no. 1, pp. 24-27, (2016)

26. Y. Zhang, H. Li, and X. Wang, "Electricity market decision support system for power plants," in 2017 9th International Conference on Modelling, Identification and Control (ICMIC), pp. 935-939. (2017)

27. S. A. Eroshenko and A. I. Khalyasmaa, "Intelligent model of decision support system of distributed generation integration," in 2017 8th IEEE International Conference on Software Engineering and Service Science (ICSESS), pp. 79-82. (2017)

28. S. Kusumadewi and S. Hartatik, Neuro fuzzy: Integrasi Sistem Fuzzy \& Jaringan Syaraf. (Yogyakarta: Graha Ilmu, 2006)

29. S. Kusumadewi, Artificial Intelligence, 1st ed. Yogyakarta: Graha Ilmu, 2003.

30. S. Kusumadewi and H. Purnomo, Aplikasi Logika Fuzzy untuk Pendukung Keputusan. (Yogyakarta: Graha Ilmu, 2004)

31. I. Wahyuni, W. F. Mahmudy, and A. Iriany, "Rainfall prediction in Tengger region Indonesia using Tsukamoto fuzzy inference system," in 2016 1st International Conference on Information Technology, Information Systems and Electrical Engineering (ICITISEE), pp. 130-135. (2016)

32. B. S. Ardika, A. H. Setianingrum, and N. Hakiem, "Funding eligibility decision support system using fuzzy logic Tsukamoto: (Case: BMT XYZ)," in 2017 Second International Conference on Informatics and Computing (ICIC), pp. 1-7. (2017)

33. G. E. Pribadi, U. Syaripudin, and W. Uriawan, "Aplikasi Pembelajaran Bahasa Sunda Dengan Implementasi Algoritma Linear Congruential Generator Dan Fuzzy Berbasis Android," JOIN (Jurnal Online Inform., vol. 1, no. 1, pp. 34-42, (2016) 
34. I. Septiana, M. Irfan, and A. R. Atmadja, "Sistem Pendukung Keputusan Penentu Dosen Penguji Dan Pembimbing Tugas Akhir Menggunakan Fuzzy Multiple Attribute Decision Makingdengan Simple Additive Weighting (Studi Kasus: Jurusan Teknik Informatika Uin Sgd Bandung)," J. Online Inform., vol. 1, no. 1, pp. 43-50, (2016)

35. I. Haditama, C. Slamet, and D. Fauzy, "Implementasi Algoritma Fisher-Yates Dan Fuzzy Tsukamoto Dalam Game Kuis Tebak Nada Sunda Berbasis Android," J. Online Inform., vol. 1, no. 1, pp. 51-58, Jun. (2016)

36. I. Wahyuni and F. Utaminingrum, "Error numerical analysis for result of rainfall prediction between Tsukamoto FIS and hybrid Tsukamoto FIS with GA," in 2016 International Conference on Advanced Computer Science and Information Systems (ICACSIS), pp. 365-372. (2016)

37. T. Hastono, A. J. Santoso, and Pranowo, "Honey yield prediction using Tsukamoto fuzzy inference system," in 2017 4th International Conference on Electrical Engineering, Computer Science and Informatics (EECSI), pp. 1-6. (2017) 